\title{
50. QUATERNARY GEOMAGNETIC SECULAR VARIATION AND POLARITY REVERSAL RECORD AT DSDP SITES 379 AND 380, BLACK SEA
}

\author{
Ernest A. Hailwood and Norman Hamilton, University of Southampton, United Kingdom
}

\begin{abstract}
A paleomagnetic study of a 6-meter section of varved sediment, of probable age $>700,000 \mathrm{yr}$, at DSDP Black Sea Hole $380 \mathrm{~A}$, has revealed fluctuations in inclination of remanent magnetism that are considered to represent a record of paleosecular variation of the geomagnetic field. Inclination variations having a periodicity of 2800 years have been previously identified for the interval 7000 to 25,000 years B.P. in a radiometrically dated surface piston core from the Black Sea (Creer, 1974) and assuming a similar periodicity for the fluctuations recorded in the older sediments sampled from Hole $380 \mathrm{~A}$, a mean accumulation rate of 1.2 meters per thousand years is derived for these sediments.

On the basis of magnetic polarity determinations from a further four samples from Holes $380 / 380 \mathrm{~A}$, and four from Site 379 , the Brunhes/Matuyama magnetic epoch boundary, corresponding to an age of 700,000 years, is tentatively assigned to a maximum depth of 800 meters subbottom at Holes $380 / 380 \mathrm{~A}$, and 475 meters at Hole 379A.
\end{abstract}

\section{INTRODUCTION}

The characteristics of variations in the Earth's magnetic field over time scales ranging from years to millions of years have important bearings on the nature and location of possible geomagnetic field sources. Furthermore, such changes, recorded in both sedimentary and igneous formations, are proving to be of great value as a tool for geological correlation purposes (e.g., Creer et al., 1972; Blow and Hamilton, 1974; Hailwood et al., 1976). For these reasons it is of some considerable interest to investigate the characteristic amplitudes and periodicities of these changes, ranging from field reversals, with time scales of $10^{5}$ to $10^{6}$ years to secular variations with time scales of $10^{2}$ to $10^{4}$ years and amplitudes of some tens of degrees.

Due to very slow rates of accumulation, most continuously deposited abyssal sediments are unsuitable for studying short-period geomagnetic field variations, and most reliable information on this time scale has been obtained from fresh water lake deposits (e.g., Creer et al., 1972). In the majority of these cases a continuous sedimentary record is restricted to postglacial times. However Creer (1974) has described a detailed paleomagnetic study of an 11-meter piston core from the Black Sea, spanning the interval 7000 to $25,000 \mathrm{yr}$ B.P., and has observed clear variations in the magnetic inclination, with a period of approximately $2800 \mathrm{yr}$, deduced from five radiocarbon dates along the core. The period of these inclination fluctuations is very similar to that of declination fluctuations $(2700 \mathrm{yr})$ recorded in sediments from Lake Windemere, UK (Mackereth, 1971), during the past $10,000 \mathrm{yr}$. This similarity suggests that the variations might be due to oscillation of the same geomagnetic field source in the Earth's core, and the fact that this pulsation is manifested in declination variations at Windermere, and inclination variations in the Black Sea may be explained by the source-station geometry (Creer, 1974). From the standpoint of geomagnetic theory it is of profound importance to investigate the extent to which variations having similar periodicities have persisted throughout earlier geological periods, and whether or not other, longer period variations can be identified.

The Quaternary and late Tertiary sediments of the Black Sea appear to represent a continuous section and sedimentation rates have been consistently high, in the range 10 to $80 \mathrm{~cm}$ per thousand years for at least the past 20,000 years. Consequently these sediments are likely to be particularly suitable for studies of relatively high-frequency paleosecular variation of the geomagnetic field. Unfortunately large portions of the sequence recovered by DSDP drilling on Leg 42B were badly disturbed due to high gas content, and suitable material for paleomagnetic study was only available from certain very restricted depth ranges. These include several continuous laminated "varve-like" sequences, which offer the additional advantage of an independent age estimate (assuming that the varves represent annual/seasonal changes).

For this preliminary study 24 closely spaced samples were selected (average spacing $0.25 \mathrm{~m}$ ) from Core 380A-51. Since very few diagnostic microfossils have been retrieved from these cores, paleontological age determinations are fragmentary and uncertain. Consequently an additional four paleomagnetic samples were taken from both Holes $380 / 380 \mathrm{~A}$ and $379 \mathrm{~A}$, to search for possible magnetic reversals, and establish if the Brunhes/Matuyama Epoch boundary (about 700,00 yr B.P.) had been penetrated at these sites. 


\section{SAMPLE PREPARATION AND MEASUREMENT}

Cylindrical samples, approximately $2.5 \mathrm{~cm}$ in diameter and height, were taken by pushing plastic sample holders into the split core sections. Care was exercised to avoid disturbance of the sediment during this process. The samples were taken with their cylindrical axes accurately perpendicular to the split longitudinal face of the core section, in order to preserve orientation with respect to the horizontal and "relative" azimuth in each core section. The uphole direction was carefully recorded on the face of each sample by means of an orientation arrow. The samples were subsequently trimmed to size and their ends sealed with adhesive tape. In the case of a few samples of very friable finely laminated lutite, it was necessary to seal the ends with epoxy resin, to prevent movement of the sample within the plastic holder.

Measurements of remanent magnetization were performed on a "Digico" computerized spinner magnetometer (Molyneux, 1971). The intensities of Natural Remanent Magnetization (NRM) of these sediments were typically in the range 0.2 to $0.9 \times 10^{-6}$ Gauss (with a few samples an order of magnitude higher), and consequently a long spin integration time corresponding to $2^{9}$ revolutions was necessary, in order to decrease the instrumental noise to an acceptably low level ( 0.02 to $0.05 \times 10^{-6}$ Gauss). In view of the low NRM intensities, all measurements were made in duplicate to provide an estimate of their reliability.

Alternating field demagnetization was carried out on a "Highmoor" electronically controlled demagnetizer, utilizing a 2-axis tumbler system, to examine the stability of the remanence, and to remove low coercivity components.

\section{RESULTS}

\section{Site 380}

Figure 1 shows a downhole plot of the NRM directions and intensities for Core 380-51. The error bars represent an estimate of the repeatability of duplicate measurements for each sample (Table 1). The relative declination values show several large swings, approximately centered on the fiducial line, and there appear to be no abrupt changes in mean declination between the different core sections that might indicate loss of relative azimuthal orientation. The NRM inclinations are dominantly positive and cluster about a value of $+50^{\circ}$ in the upper sections, but several zones of negative inclination are present in the lower sections.

Five samples from Hole $380 \mathrm{~A}$ were initially demagnetized in alternating fields up to 300 oe. The directional response of these samples is illustrated in Figure 2 and in all cases the inclinations change from a positive to a negative value after treatment at 100 oe. Figure 3 shows a plot of the normalized remanent intensities of these samples during demagnetization.

For the three samples from Sections 380A-51-1 and 380A-51-2 (crosses and open circles in Figure 3) the intensity decreases on treatment at 50 ot 100 oe and thereafter shows a steady increase on treatment to 200 oe, followed by a further decrease. This behavior is consistent with the existence of three components of magnetization, A, B, and C (Figure 4), corresponding, respectively, to the geomagnetic field direction at the time of deposition, the present (or axial geocentric dipole) field direction at the sampling site, and the present field direction in the laboratory. Components A to $\mathrm{C}$ must reside in grains of successively lower (but possibly partially overlapping) coercivity. Progressive demagnetization would then first remove component $\mathrm{C}$, causing a decrease in intensity and a change in direction towards the resultant of components A and B. Further demagnetization would preferentially remove component $\mathrm{B}$, this time causing an increase in the resultant magnetization. Finally, when only component A remains, the intensity will decrease again with further treatment. In the samples from Sections 380A-1 and $380 \mathrm{~A}-2$ this point appears to have been reached after treatment at $200 \mathrm{oe}$, and it is considered that demagnetization at this level gives a reasonably precise definition of the geomagnetic field direction at the time of deposition of these sediments. Of the remaining two samples, $380 \mathrm{~A}-51-4,28-30 \mathrm{~cm}$, appears to have reached a directionally stable end point after treatment at 150 oe, although the intensity of magnetization continues to rise on further treatment to $300 \mathrm{oe}$. This behavior is difficult to explain but may be due to the acquisition of a small anhysteretic magnetization due to instrumental effects. Intensity changes are much smaller for Sample $380 \mathrm{~A}-51-4,116-118 \mathrm{~cm}$, but once again a stable direction appears to have been reached at 150 oe (Figure 2). In view of the above behavior, it was concluded that treatment at 200 oe would suffice to remove magnetically soft components from these sediments, but as a precaution against possible loss of information through too intense demagnetization, the remaining samples were all subjected to treatment at 50 and $100 \mathrm{oe}$, as well as $200 \mathrm{oe}$.

Histograms of the inclination values for all samples from Core $380 \mathrm{~A}-51$ during this treatment are plotted in Figure 5. Whereas the NRM inclinations show a slight skewness towards positive values, treatment at 50 and 100 oe causes a gradual displacement towards negative values, and by 200 oe there is a clearly defined peak, centered in the range $-30^{\circ}$ to $-60^{\circ}$. This behavior demonstrated the successful removal of low coercivity downward directed components and the isolation of a stable high coercivity component of reversed polarity throughout Core 380A-51. The apparent reversals in the NRM inclination values (Figure 1) are due to the variable magnitude of these low coercivity normal polarity components.

The downhole variation of paleomagnetic direction and intensity after 200 oe treatment is shown in Figure 6 . Because of the possibility of relative rotation having occurred between different parts of the core during drilling, the reliability of the declination values is uncertain and no further analysis of them will be attempted here.

The intensities of magnetization after 200 oe treatment remain within the same range as the NRM values, but a zone of variable and generally high 

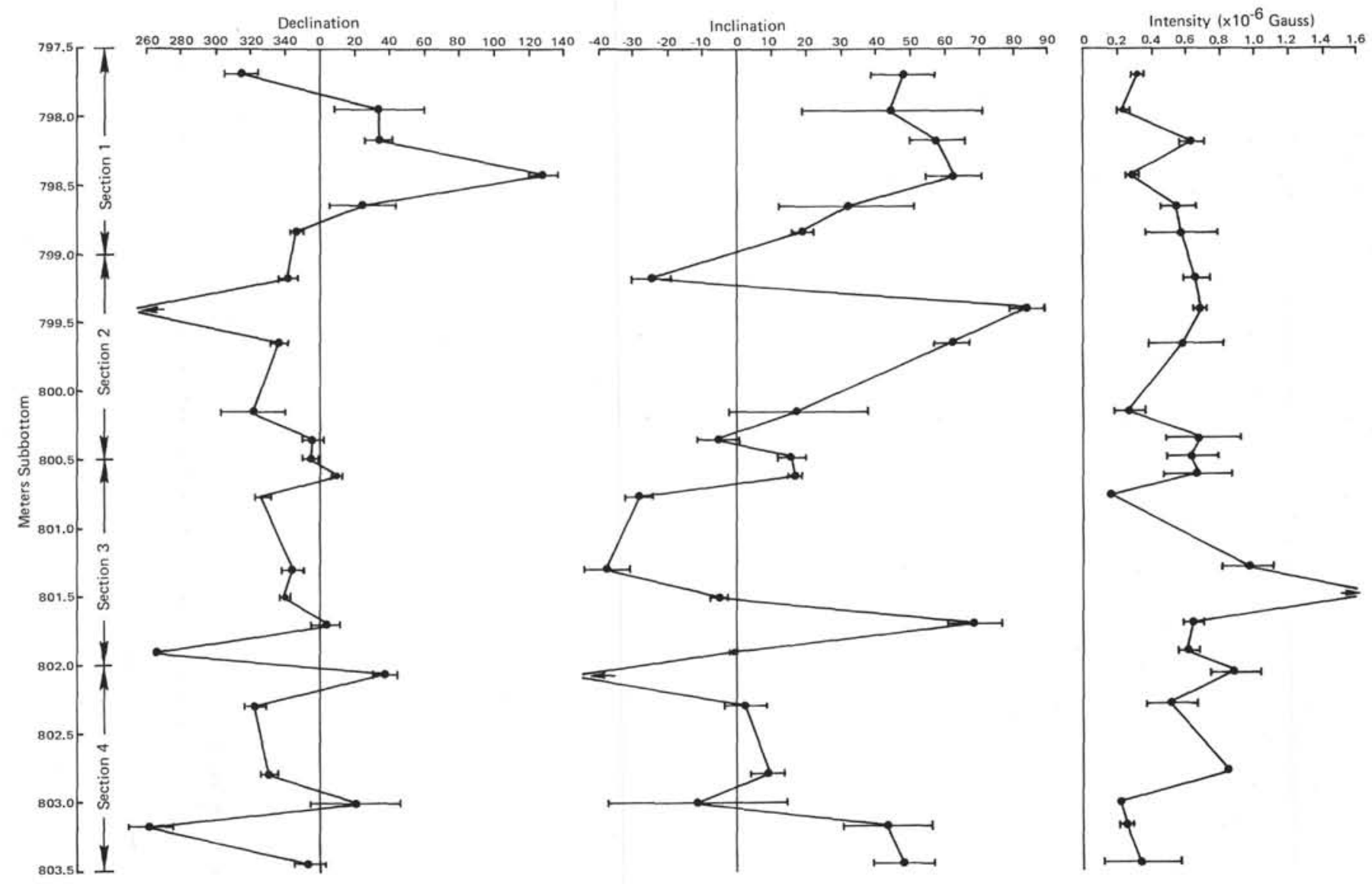

Figure 1. Core 380A-51. Downhole plot of paleomagnetic directions and intensities before laboratory demagnetization. (Note that angular scale for declination is half that for inclination.)

intensities can be distinguished in the depth range 800.2 to 801.6 meters. The inclination values show some variability but if points corresponding to samples with poor repeatability are omitted, this record appears to show a long-term periodicity, with approximately one and one-half cycles being represented in the total length of core sampled. However the number of samples is considered too small to justify smoothing by running means, or other more sophisticated filtering and statistical analysis.

It is highly probable that the observed changes in remanent intensity represent variations in supply of a terrigenous component, due to changes in source area or sediment transport path. Similarly, it is possible that the apparently cyclic changes in magnetic inclination could represent fluctuations in the influence of depositional factors causing deviation of the remanence direction from that of the ambient geomagnetic field. The occurrence of such "inclination errors" has been demonstrated in the laboratory (Griffiths et al., 1962), and in the case of some rapidly deposited silts and sands in nature (Blow and Hamilton, 1974). Furthermore, the overall mean inclination for Core $380 \mathrm{~A}-51$, after AF cleaning, and elimination of samples showing poor repeatability, is $53^{\circ}$, which is some $9^{\circ}$ less than the theoretical axial geocentric dipole value for the present latitude of Site 380 . Thus there is some evidence that a persistent inclination error might be present in these sediments. However, no sedimentological features have been identified (such as a regular variation in grain size) that could be associated with variations in the influence of factors causing this error, and therefore account for the observed cyclical change in inclination. We therefore favor the alternative interpretation, that these changes represent a record of secular variation of the geomagnetic field. The existence of this record implies that the stable reversed remanence revealed by partial $\mathrm{AF}$ demagnetization in Core $380 \mathrm{~A}-51$ represents a primary magnetization acquired at, or close to, the time of initial deposition of the sediments. It is possible that the observed "inclination error" of $9^{\circ}$ is due to the incomplete averaging of a still longer period component of secular variation, superimposed on the observed cyclic changes.

\section{Sedimentation Rates at Holes 380/380A}

If we postulate that the inclination variations of periodicity $2800 \mathrm{yr}$ identified by Creer $(1974)$ in Black Sea sediments for the interval 7000 to $25,000 \mathrm{yr}$ B.P. have persisted throughout most of the Quaternary, and are represented by the inclination fluctuations observed in Core 380A-51, then we can calculate the corresponding mean accumulation rate for these sediments. One complete cycle of inclination variation occurs in a thickness of approximately 3.5 meters of sediment (Figure 6). Assuming this thickness to represent $2800 \mathrm{yr}$, the corresponding accumulation rate is 1.2 meters per thousand years, which agrees reasonably well with the approximate figure of 1 meter per thousand years deduced from paleontology and 
TABLE 1

Paleomagnetic Results From Core 380A-51

\begin{tabular}{|c|c|c|c|c|c|c|c|c|c|c|c|c|c|}
\hline \multirow[b]{2}{*}{$\begin{array}{c}\text { Sample } \\
\text { (Interval in } \mathrm{cm} \text { ) }\end{array}$} & \multirow[b]{2}{*}{$\begin{array}{l}\text { Depth } \\
\text { (m) }\end{array}$} & \multicolumn{3}{|c|}{ NRM } & \multicolumn{3}{|c|}{$50 \mathrm{oe}$} & \multicolumn{3}{|c|}{100 oe } & \multicolumn{3}{|c|}{200 oe } \\
\hline & & Decl. & Incl. & $\begin{array}{l}\text { Int } \pm \\
\text { SD }\end{array}$ & Decl. & Incl. & $\begin{array}{c}\text { Int } \pm \\
\text { SD }\end{array}$ & Decl. & Incl. & $\begin{array}{l}\text { Int } t \\
\text { SD }\end{array}$ & Decl. & Incl. & $\begin{array}{l}\text { Int } \pm \\
\text { SD }\end{array}$ \\
\hline $1,17-19$ & 797.68 & 315.1 & 47.9 & $\begin{array}{l}0.32 \pm \\
0.03\end{array}$ & 355.7 & 22.6 & $\begin{array}{l}0.25 \pm \\
0.06\end{array}$ & 322.6 & 43.2 & $\begin{array}{l}0.46 \pm \\
0.19\end{array}$ & 318.5 & -41.7 & $\begin{array}{l}0.62 \pm \\
0.02\end{array}$ \\
\hline $51-1,44-46$ & 797.95 & 33.6 & 44.9 & $\begin{array}{l}0.24 \pm \\
0.03\end{array}$ & 2.9 & 68.7 & $\begin{array}{l}0.46 \pm \\
0.11\end{array}$ & 14.3 & -33.2 & $\begin{array}{l}0.15 \pm \\
0.02\end{array}$ & 11.6 & -50.5 & $\begin{array}{l}0.51 \pm \\
0.03\end{array}$ \\
\hline $51-1,66-68$ & 798.17 & 34.3 & 57.9 & $\begin{array}{l}0.64 \pm \\
0.07\end{array}$ & 216.7 & 3.6 & $\begin{array}{l}0.15 \pm \\
0.05\end{array}$ & 104.4 & -28.1 & $\begin{array}{l}0.20 \pm \\
0.06\end{array}$ & 57.9 & -59.7 & $\begin{array}{l}0.26 \pm \\
0.07\end{array}$ \\
\hline $51-1,91-93$ & 798.42 & 128.8 & 62.6 & $\begin{array}{l}0.29 \pm \\
0.03\end{array}$ & 128.8 & 69.2 & $\begin{array}{l}0.20 \pm \\
0.05\end{array}$ & 168.3 & 39.8 & $\begin{array}{l}0.10 \pm \\
0.01\end{array}$ & 254.7 & -59.9 & $\begin{array}{l}0.07 \pm \\
0.01\end{array}$ \\
\hline $51-1,114-116$ & 798.65 & 25.4 & 31.9 & $\begin{array}{l}0.56 \pm \\
0.10\end{array}$ & 52.9 & 35.7 & $\begin{array}{l}0.24 \pm \\
0.04\end{array}$ & 28.3 & 15.9 & $\begin{array}{l}0.11 \pm \\
0.01\end{array}$ & 15.7 & -48.5 & $\begin{array}{l}0.06 \pm \\
0.02\end{array}$ \\
\hline $51-1,132-134$ & 798.83 & 346.8 & 19.0 & $\begin{array}{l}0.58 \pm \\
0.21\end{array}$ & 300.5 & 29.1 & $\begin{array}{l}0.45 \pm \\
0.08\end{array}$ & 299.3 & -5.9 & $\begin{array}{l}0.19 \pm \\
0.03\end{array}$ & 312.7 & -52.4 & $\begin{array}{l}0.29 \pm \\
0.00\end{array}$ \\
\hline $51-2,16-18$ & 799.17 & 342.0 & -24.4 & $\begin{array}{l}0.66 \pm \\
0.08\end{array}$ & 355.0 & -10.8 & $\begin{array}{l}0.34 \pm \\
0.03\end{array}$ & 304.8 & -8.5 & $\begin{array}{l}0.09 \pm \\
0.02\end{array}$ & 252.4 & -11.0 & $\begin{array}{l}0.22 \pm \\
0.09\end{array}$ \\
\hline $51-2,38-40$ & 799.39 & 201.4 & 83.8 & $\begin{array}{l}0.69_{ \pm} \\
0.13\end{array}$ & 9.9 & -15.7 & $\begin{array}{l}0.36 \pm \\
0.00\end{array}$ & 5.0 & -28.0 & $\begin{array}{l}0.34 \pm \\
0.00\end{array}$ & 358.9 & -33.4 & $\begin{array}{l}0.39 \pm \\
0.01\end{array}$ \\
\hline $51-2,65-67$ & 799.66 & 337.2 & 62.2 & $\begin{array}{l}0.60 \pm \\
0.22\end{array}$ & 313.6 & 31.4 & $\begin{array}{l}0.18 \pm \\
0.01\end{array}$ & 253.8 & -36.9 & $\begin{array}{l}0.21 \pm \\
0.02\end{array}$ & 274.6 & -49.5 & $\begin{array}{l}0.30 \pm \\
0.05\end{array}$ \\
\hline $51-2,115-117$ & 800.16 & 322.2 & 18.3 & $\begin{array}{l}0.27 \pm \\
0.09\end{array}$ & 326.4 & 27.2 & $\begin{array}{l}0.14 \pm \\
0.02\end{array}$ & 48.3 & 6.6 & $\begin{array}{l}0.08 \pm \\
0.03\end{array}$ & 303.8 & -37.9 & $\begin{array}{l}0.15 \pm \\
0.03\end{array}$ \\
\hline $51-2,134-136$ & 800.35 & 356.1 & -5.0 & $\begin{array}{l}0.69 \pm \\
0.22\end{array}$ & 1.6 & 40.8 & $\begin{array}{l}0.93 \pm \\
0.07\end{array}$ & 340.2 & -26.6 & $\begin{array}{l}0.94 \pm \\
0.23\end{array}$ & 329.9 & -41.8 & $\begin{array}{l}1.61 \pm \\
0.18\end{array}$ \\
\hline $51-2,147-149$ & 800.46 & 354.9 & 16.0 & $\begin{array}{l}0.64 \pm \\
0.15\end{array}$ & 312.3 & 4.6 & $\begin{array}{l}0.11 \pm \\
0.06\end{array}$ & 319.0 & -28.9 & $\begin{array}{l}0.15 \pm \\
0.01\end{array}$ & 313.9 & -40.7 & $\begin{array}{l}0.26 \pm \\
0.00\end{array}$ \\
\hline $51-3,11-13$ & 800.62 & 10.4 & 16.7 & $\begin{array}{l}0.67 \pm \\
0.20\end{array}$ & 42.8 & 7.3 & $\begin{array}{l}0.32 \pm \\
0.01\end{array}$ & 60.0 & -59.4 & $\begin{array}{l}0.46 \pm \\
0.02\end{array}$ & 65.3 & -63.0 & $\begin{array}{l}0.51 \pm \\
0.07\end{array}$ \\
\hline $51-3,25-27$ & 800.76 & 327.3 & -28.1 & $\begin{array}{l}0.17 \pm \\
0.02\end{array}$ & 301.8 & -41.4 & $\begin{array}{l}0.21 \pm \\
0.00\end{array}$ & 295.7 & -57.8 & $\begin{array}{l}0.31 \pm \\
0.02\end{array}$ & 303.4 & -61.1 & 0.45 \\
\hline $51-3,80-82$ & 801.31 & 345.5 & -37.3 & $\begin{array}{l}0.96 \pm \\
0.15\end{array}$ & 210.5 & -27.9 & $\begin{array}{l}1.23 \pm \\
0.09\end{array}$ & 206.4 & -59.1 & $\begin{array}{l}1.37 \pm \\
0.02\end{array}$ & 208.7 & -69.3 & $\begin{array}{l}1.69 \pm \\
0.06\end{array}$ \\
\hline $51-3,100-102$ & 801.51 & 339.7 & -4.8 & $\begin{array}{l}2.76 \pm \\
0.12\end{array}$ & 327.8 & -29.4 & $\begin{array}{l}2.26 \pm \\
0.08\end{array}$ & 328.6 & -40.3 & $\begin{array}{l}2.82 \pm \\
0.09\end{array}$ & 334.1 & -49.5 & $\begin{array}{l}3.26 \pm \\
0.20\end{array}$ \\
\hline $51-3,119-121$ & 801.70 & 4.2 & 68.8 & $\begin{array}{l}0.65 \pm \\
0.06\end{array}$ & 80.1 & 35.1 & $\begin{array}{l}0.38 \pm \\
0.07\end{array}$ & 107.3 & -39.5 & 0.22 & 87.1 & -80.0 & 0.57 \\
\hline $51-3,138-140$ & 801.89 & 267.1 & -0.9 & $\begin{array}{l}0.62 \pm \\
0.04\end{array}$ & 261.4 & 13.7 & 0.60 & 254.0 & 11.1 & 0.49 & 257.9 & 6.2 & 0.38 \\
\hline $51-4,5-7$ & 802.06 & 38.1 & -80.5 & $\begin{array}{l}0.89 \pm \\
0.15\end{array}$ & 85.4 & -34.2 & 0.44 & 121.7 & -54.8 & 0.81 & 130.1 & -60.0 & 0.91 \\
\hline $51-4,28-30$ & 802.29 & 323.4 & 2.4 & $\begin{array}{l}0.52 \pm \\
0.15\end{array}$ & 311.5 & 43.5 & $\begin{array}{l}0.34 \pm \\
0.03\end{array}$ & 37.9 & -59.8 & $\begin{array}{l}0.16 \pm \\
0.00\end{array}$ & 98.5 & -62.4 & $\begin{array}{l}0.46 \pm \\
0.03\end{array}$ \\
\hline $51-4,78-80$ & 802.79 & 331.2 & 8.9 & $\begin{array}{l}0.86 \pm \\
0.01\end{array}$ & 339.2 & 6.8 & $\begin{array}{l}0.33 \pm \\
0.01\end{array}$ & 337.7 & -0.5 & $\begin{array}{l}0.13 \pm \\
0.02\end{array}$ & 100.6 & -72.8 & $\begin{array}{l}0.17 \pm \\
0.04\end{array}$ \\
\hline $51-4,99-101$ & 803.00 & 20.6 & -10.9 & $\begin{array}{l}0.23 \pm \\
0.01\end{array}$ & 34.2 & 11.9 & $\begin{array}{l}0.10 \pm \\
0.06\end{array}$ & 338.6 & 23.7 & $\begin{array}{l}0.15 \pm \\
0.02\end{array}$ & 317.2 & -18.8 & $\begin{array}{l}0.12 \pm \\
0.02\end{array}$ \\
\hline $51-4,116-118$ & 803.17 & 262.5 & 43.3 & $\begin{array}{l}0.26 \pm \\
0.03\end{array}$ & 287.2 & 25.8 & $\begin{array}{l}0.27 \pm \\
0.00\end{array}$ & 282.1 & -11.2 & 0.22 & 287.0 & -42.5 & 0.22 \\
\hline $51-4,144-146$ & 803.45 & 353.9 & 47.9 & $\begin{array}{l}0.34 \pm \\
0.22\end{array}$ & 22.2 & 43.8 & $\begin{array}{l}0.40 \pm \\
0.03\end{array}$ & 298.8 & 11.4 & $\begin{array}{l}0.08 \pm \\
0.01\end{array}$ & 228.2 & -52.6 & $\begin{array}{l}0.57 \pm \\
0.10\end{array}$ \\
\hline
\end{tabular}

varve chronology (Leg 42B Hole Summary). Since the figure of 1.2 meters/thousand years is based on a single cycle of variation, a higher accuracy could probably be achieved by extending the paleomagnetic observations to a sediment thickness corresponding to several cycles, but widespread deformation of these sediments makes it unlikely that a suitably thick undisturbed portion of core is available from Hole $380 \mathrm{~A}$.

The reasonably close agreement between the paleomagnetically determined sedimentation rate and that deduced from paleontology and varve chronology supports the initial assumption of a periodicity close to 


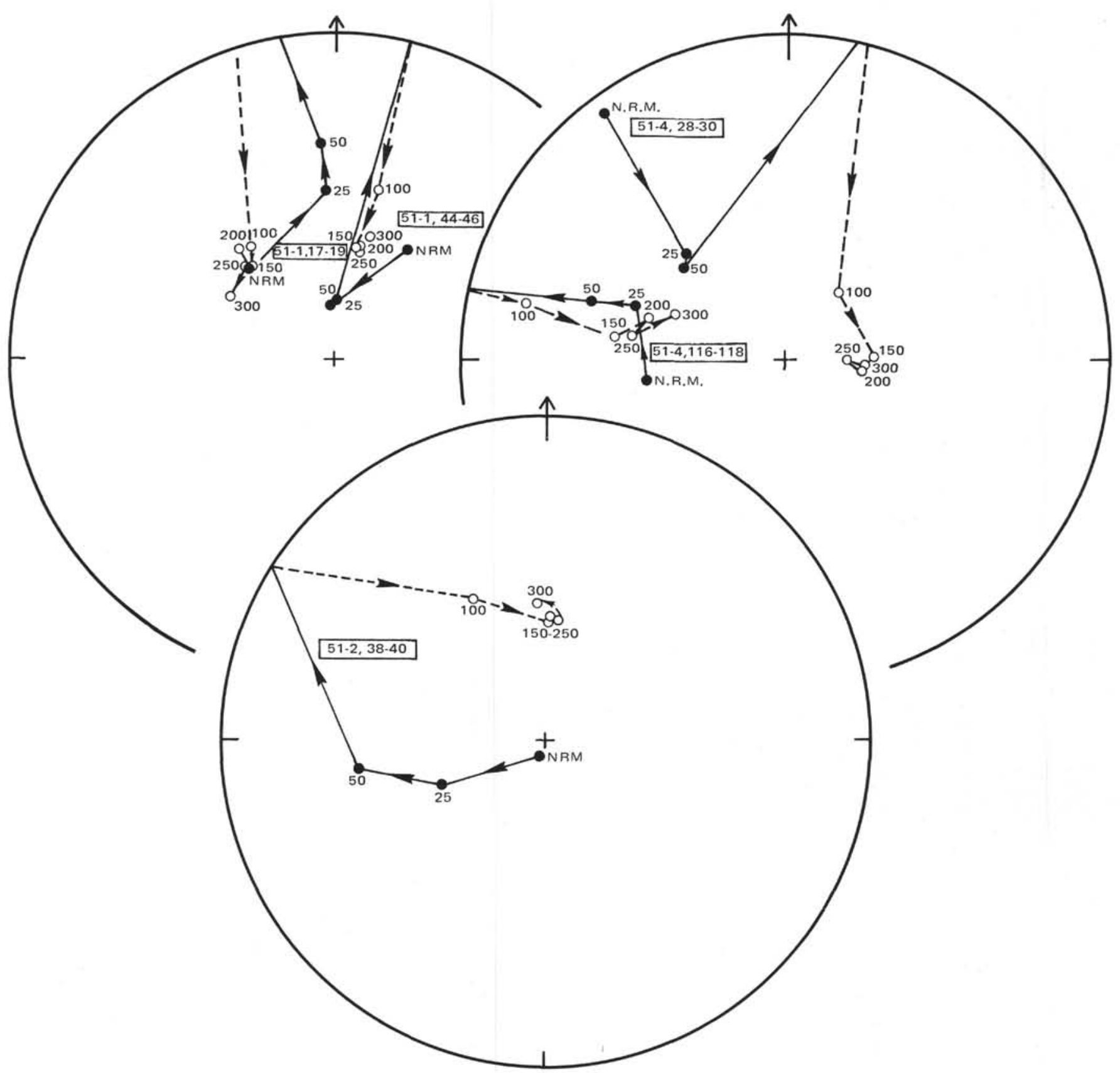

Figure 2. Examples of directional response to AF demagnetization of samples from Core 380A-51. Solid symbols represent positive inclinations (directed downwards) and open symbols negative inclinations. Numbers refer to demagnetizing field value in Oersteds.

$2800 \mathrm{yr}$ in the inclination fluctuations and implies that the source of these geomagnetic pulsations might have remained approximately stationary for the past 1 million years. This has important implications for geomagnetic theory.

\section{Polarity Stratigraphy}

A further four widely spaced samples were taken from above Core 380A-51 (Table 2), and each of these was demagnetized at 25,50 , and $200 \mathrm{oe}$. The uppermost three samples exhibit a high degree of stability and measurement repeatability, and all three samples have a positive inclination, corresponding to a normal magnetic polarity. The fourth sample has a much weaker intensity of magnetization, so that the repeatability and apparent stability is poor, but it also has a normal polarity. Conversely the 24 samples from Core $380 \mathrm{~A}-51$, discussed above, have a clearly defined reverse polarity; and the simplest explanation for this situation is that Core $380 \mathrm{~A}-51$ was deposited during the Matuyama reversed magnetic epoch, giving a minimum age of 0.7 m.y.B.P. and a maximum age of $2.4 \mathrm{~m} . y$. B.P. for these sediments (Figure 7).

\section{Hole 379A}

The four paleomagnetic samples from Hole 379A were subjected to progressive AF demagnetization up to $300 \mathrm{oe}$, and the results are listed in Table 3. In all 


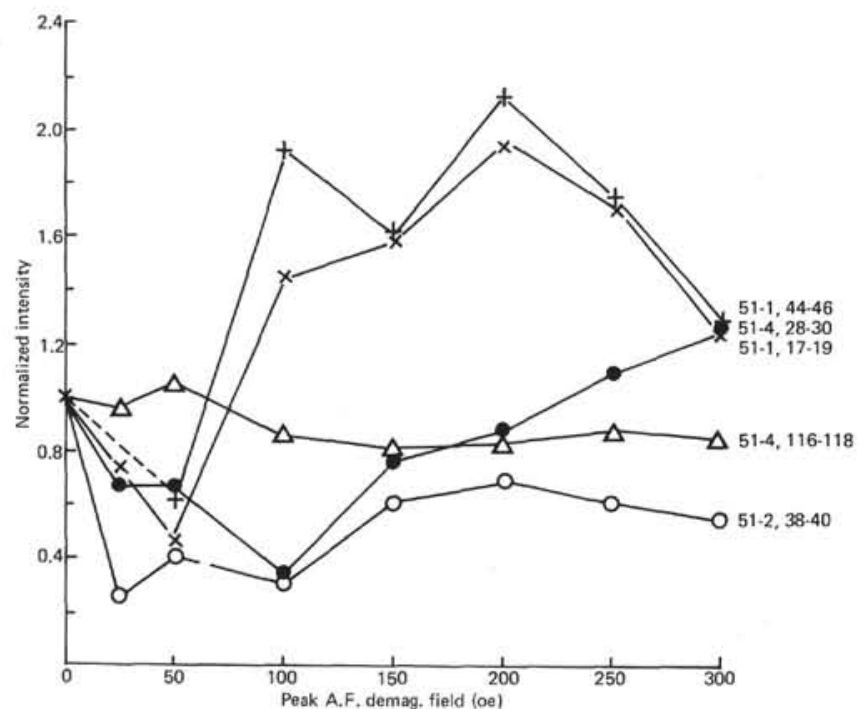

Figure 3. Normalized intensity curves for samples plotted in Figure 2.

(i) Orientation of sample in situ (before drilling)
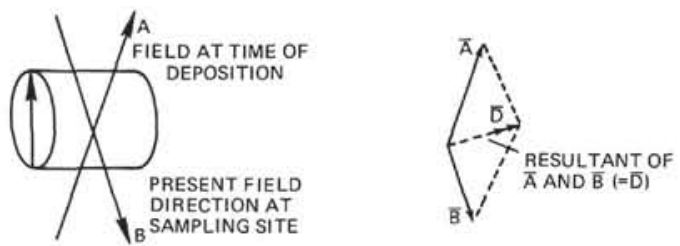

(ii) Orientation during storage in the laboratory
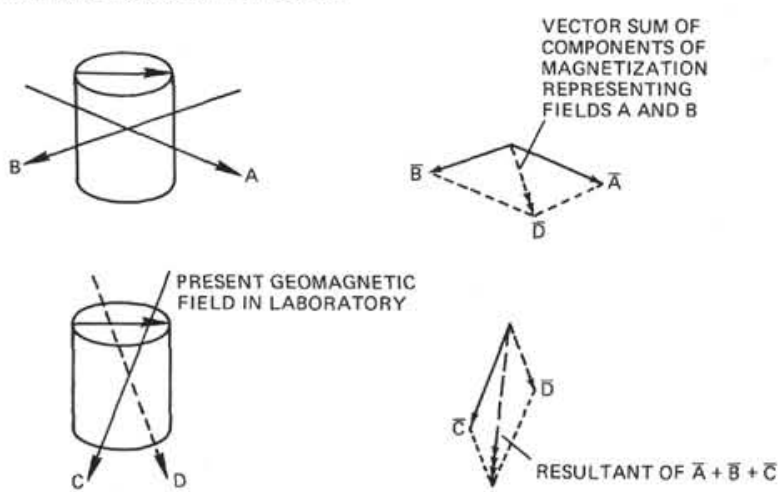

Figure 4. Possible model for multicomponent remanence in samples from Sections 380A-51-1 and 380A-51-2.

cases the repeatability is high and the magnetization of all four samples is very stable, with only small changes in direction occurring, as small low-coercivity components are removed. The polarity of these samples is clearly defined as normal for the uppermost sample and reverse for the lower three samples, taken from below 475 meters subbottom (Figure 7). Once again, the simplest interpretation of these results is that the Brunhes/Matuyama Epoch boundary, corresponding to an age of 700,000 years B.P. has been penetrated, in this case between 145 and 475 meters subbottom. The
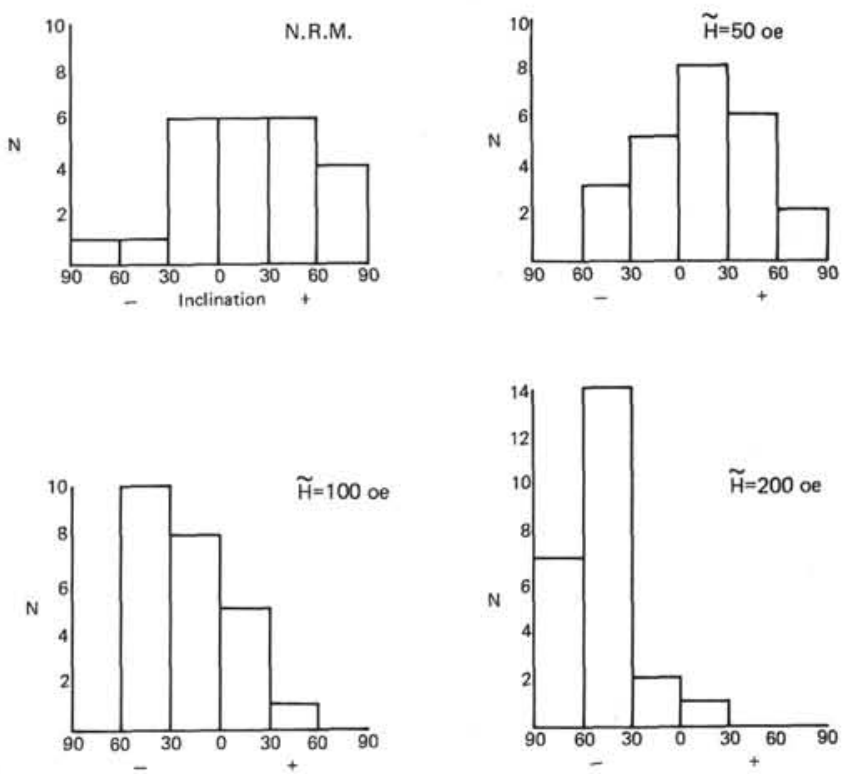

Figure 5. Histograms of inclination values for Core 380A-51.

minimum mean sedimentation rate for the section above 475 meters subbottom at this site would then be 0.7 meters per thousand years and extrapolating this rate to the base of the core, the minimum age of the deepest sediments penetrated would be 900,000 years B.P. This is significantly older than the preliminary paleontological age estimate of between 230,000 and 700,000 yr B.P.

\section{ACKNOWLEDGMENTS}

We wish to express our thanks to Robert B. Kidd for his painstaking work in sampling the cores and for general help and discussion during the course of this work. We are also grateful to D. Spanner for assistance with sample preparation and preliminary measurements. The manuscript was reviewed by K.M. Creer and D.H. Tarling, whose helpful comments are gratefully acknowledged.

\section{REFERENCES}

Blow, R.A. and Hamilton, N., 1974. Geomagnetic secular variation in recent sediments from the Tyrrhenian Sea: Earth Planet. Sci. Lett., v. 22, p. 417-422.

, 1975. Palaeomagnetic evidence from DSDP cores of northward drift of India: Nature, v. 257, p. 570-572.

Creer, K.M., 1974. Geomagnetic variations for the interval 7,000-25,000 yr. B.P. as recorded in a core of sediment from station 1474 of the Black Sea cruise of "Atlantis II": Earth Planet. Sci. Lett., v. 23, p. 34-42.

Creer, K.M., Thompson, R., Molyneux, L., and Mackereth, F.J.H., 1972. Geomagnetic secular variation recorded in the stable magnetic remanence of Recent sediments: Earth Planet. Sci. Lett., v. 14, p. 115-127.

Griffiths, D.H., King, R.F., and Rees, A.I., 1962. The relevance of magnetic measurements on some fine grained silts to the study of their depositional process: Sedimentology, v. 1, p. 134-144.

Hailwood, E.A., L $\phi$ vlie, R., and Tarling, D.H., 1976. The origin of magnetization in the Tertiary basalts of Scoresby Sund, East Greenland. (Abstract): Am. Geophys. Union Trans., v. 57 , p. 655 .

Mackereth, F.H., 1971. On the variation in direction of the horizontal component of remanent magnetization in lake sediments: Earth Planet. Sci. Lett., v. 12, p. 332-338. 
Molyneux, L., 1971. A complete results magnetometer for measuring the remanent magnetization of rocks: Geophys. J. Roy. Astron. Soc., v. 24, p. 429-434.
Tarling, D.H. and Mitchell, J.G., 1976. Revised Cenozoic polarity time scale: Geology, v. 4, p. 133-136.
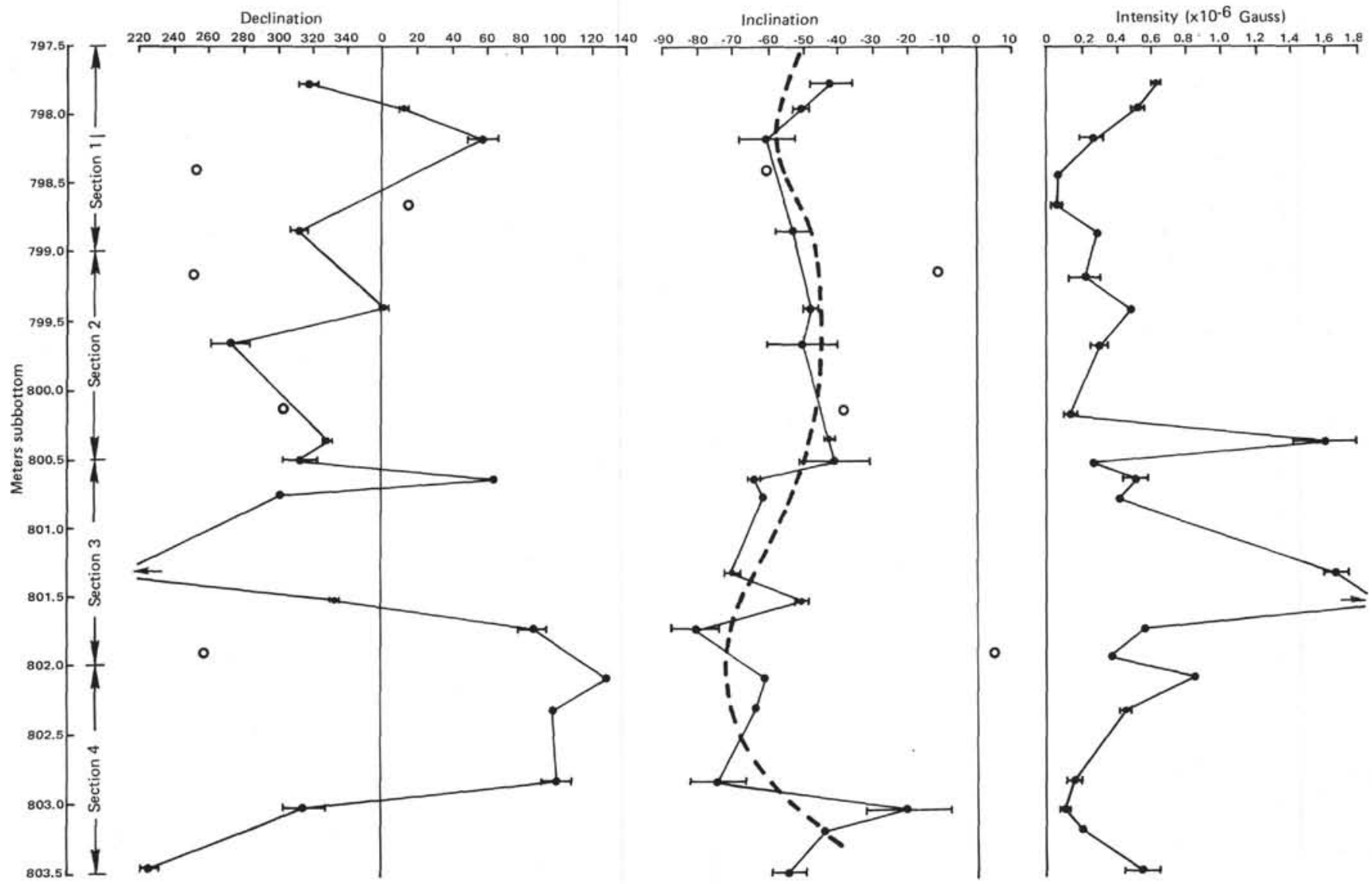

Figure 6. Core 380A-51. Downhole plot of paleomagnetic directions and intensities after AF demagnetisation at 200 oe. Solid symbols are samples with high repeatability, those with open symbols have poor repeatability.

TABLE 2

Paleomagnetic Determination for Samples Above Core 380A-51

\begin{tabular}{|c|c|c|c|c|c|c|c|c|c|c|c|c|c|}
\hline \multirow[b]{2}{*}{$\begin{array}{c}\text { Sample } \\
\text { (Interval in } \mathrm{cm} \text { ) }\end{array}$} & \multirow[b]{2}{*}{$\begin{array}{l}\text { Depth } \\
\text { (m) }\end{array}$} & \multicolumn{3}{|c|}{ NRM } & \multirow[b]{2}{*}{ Decl. } & \multicolumn{2}{|l|}{25 oe } & \multicolumn{3}{|c|}{50 oe } & \multicolumn{3}{|c|}{200 oe } \\
\hline & & Decl. & Incl. & $\begin{array}{l}\text { Int } \pm \\
\text { SD }\end{array}$ & & Incl. & $\begin{array}{l}\text { Int } \pm \\
\text { SD }\end{array}$ & Decl. & Incl. & $\begin{array}{l}\text { Int } \pm \\
\text { SD }\end{array}$ & Decl. & Incl. & $\begin{array}{l}\text { Int } \pm \\
\text { SD }\end{array}$ \\
\hline $380-36-2,129-131$ & 335.30 & 335.8 & 16.4 & $\begin{array}{l}8.69 \pm \\
0.08\end{array}$ & 323.5 & 21.9 & $\begin{array}{l}5.73 \pm \\
0.07\end{array}$ & 311.7 & 26.7 & $\begin{array}{l}3.45 \pm \\
0.04\end{array}$ & 322.5 & 34.9 & 1.22 \\
\hline $380-37-2,68-70$ & 344.19 & 294.9 & 75.5 & $\begin{array}{l}4.09 \pm \\
0.04\end{array}$ & 268.2 & 72.5 & $\begin{array}{l}4.12 \pm \\
0.02\end{array}$ & 249.3 & 68.5 & $\begin{array}{l}4.07 \pm \\
0.17\end{array}$ & 254.1 & 60.4 & $\begin{array}{l}4.20 \pm \\
0.04\end{array}$ \\
\hline $380-40-1,86-88$ & 371.37 & 40.2 & 70.8 & $\begin{array}{l}6.74 \pm \\
0.05\end{array}$ & 33.2 & 72.0 & $\begin{array}{l}6.66 \pm \\
0.09\end{array}$ & 33.6 & 71.3 & $\begin{array}{l}6.47 \pm \\
0.05\end{array}$ & 7.4 & 70.5 & $\begin{array}{l}3.32 \pm \\
0.09\end{array}$ \\
\hline $380 A-34-3,69-71$ & 640.20 & 334.0 & 59.1 & $\begin{array}{l}0.15 \pm \\
0.02\end{array}$ & - & - & - & 335.0 & 13.6 & 0.092 & 305.2 & 35.8 & 0.041 \\
\hline
\end{tabular}


TABLE 3

AF Demagnetization Results, Hole 379A

\begin{tabular}{|c|c|c|c|c|c|c|c|c|c|c|c|c|}
\hline \multirow{2}{*}{ 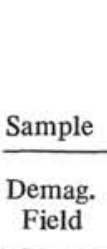 } & \multicolumn{3}{|c|}{$\begin{array}{c}379 \mathrm{~A}-16-4,98-100 \mathrm{~cm} \\
\mathrm{Jo}=(3.47 \pm 0.12) \times 10^{-6} \\
\text { Gauss } \\
\text { D.S. }^{\mathrm{a}}=145.49 \text { meters }\end{array}$} & \multicolumn{3}{|c|}{$\begin{array}{c}379 \mathrm{~A}-52-3,15-17 \mathrm{~cm} \\
\mathrm{Jo}=(7.48 \pm 0.19) \times 10^{-6} \\
\text { Gauss } \\
\text { D.S. }=475.66 \text { meters }\end{array}$} & \multicolumn{3}{|c|}{$\begin{array}{r}379 \mathrm{~A}-52-3,127-129 \mathrm{~cm} \\
\mathrm{Jo}=(9.09 \pm 0.07) \times 10^{-6} \\
\text { Gauss } \\
\text { D.S. } 476.78 \text { meters }\end{array}$} & \multicolumn{3}{|c|}{$\begin{array}{c}379 \mathrm{~A}-58-4,137-139 \mathrm{~cm} \\
\mathrm{Jo}=(30.92 \pm 0.41) \times 10^{-6} \\
\text { Gauss } \\
\text { D.S. } 535.38 \text { meters }\end{array}$} \\
\hline & Decl. & Incl. & $\mathrm{J} / \mathrm{Jo}$ & Decl. & Incl. & $\mathrm{J} / \mathrm{Jo}_{\mathrm{o}}$ & Decl. & Incl. & $\mathrm{J} / \mathrm{Jo}_{\mathrm{O}}$ & Decl. & Incl. & $\mathrm{J} / \mathrm{Jo}$ \\
\hline $\begin{array}{r}0 \\
25 \\
50 \\
100 \\
150 \\
200 \\
250 \\
300\end{array}$ & $\begin{array}{l}116.7 \\
112.5 \\
112.2 \\
111.8 \\
110.4 \\
114.1 \\
115.3 \\
123.1\end{array}$ & $\begin{array}{r}+23.8 \\
+30.6 \\
+32.4 \\
+36.4 \\
+31.1 \\
+32.4 \\
+34.8 \\
0.30\end{array}$ & $\begin{array}{l}1.00 \\
1.01 \\
1.07 \\
0.81 \\
0.60 \\
0.36 \\
0.28\end{array}$ & $\begin{array}{l}261.3 \\
266.2 \\
275.9 \\
295.4 \\
296.7 \\
298.1 \\
300.6 \\
301.7\end{array}$ & $\begin{array}{l}-23.5 \\
-27.2 \\
-31.9 \\
-32.9 \\
-36.6 \\
-39.1 \\
-40.8 \\
-39.1\end{array}$ & $\begin{array}{l}1.00 \\
1.07 \\
1.05 \\
1.25 \\
1.13 \\
0.87 \\
0.74 \\
0.60\end{array}$ & $\begin{array}{l}212.4 \\
222.5 \\
230.6 \\
238.3 \\
247.2 \\
248.9 \\
247.0 \\
254.9\end{array}$ & $\begin{array}{l}-48.3 \\
-53.9 \\
-58.2 \\
-63.7 \\
-61.5 \\
-64.5 \\
-61.8 \\
-63.6\end{array}$ & $\begin{array}{l}1.00 \\
0.87 \\
0.81 \\
0.67 \\
0.60 \\
0.50 \\
0.42 \\
0.30\end{array}$ & $\begin{array}{l}341.8 \\
345.4 \\
343.0 \\
339.8 \\
337.5 \\
336.0 \\
331.1 \\
337.3\end{array}$ & $\begin{array}{l}-30.9 \\
-34.3 \\
-37.0 \\
-39.9 \\
-42.0 \\
-41.7 \\
-46.3 \\
-38.5\end{array}$ & $\begin{array}{l}1.00 \\
1.04 \\
1.07 \\
1.00 \\
0.89 \\
0.77 \\
0.62 \\
0.65\end{array}$ \\
\hline
\end{tabular}

${ }^{\text {aDD.S. }}=$ Depth subbottom.

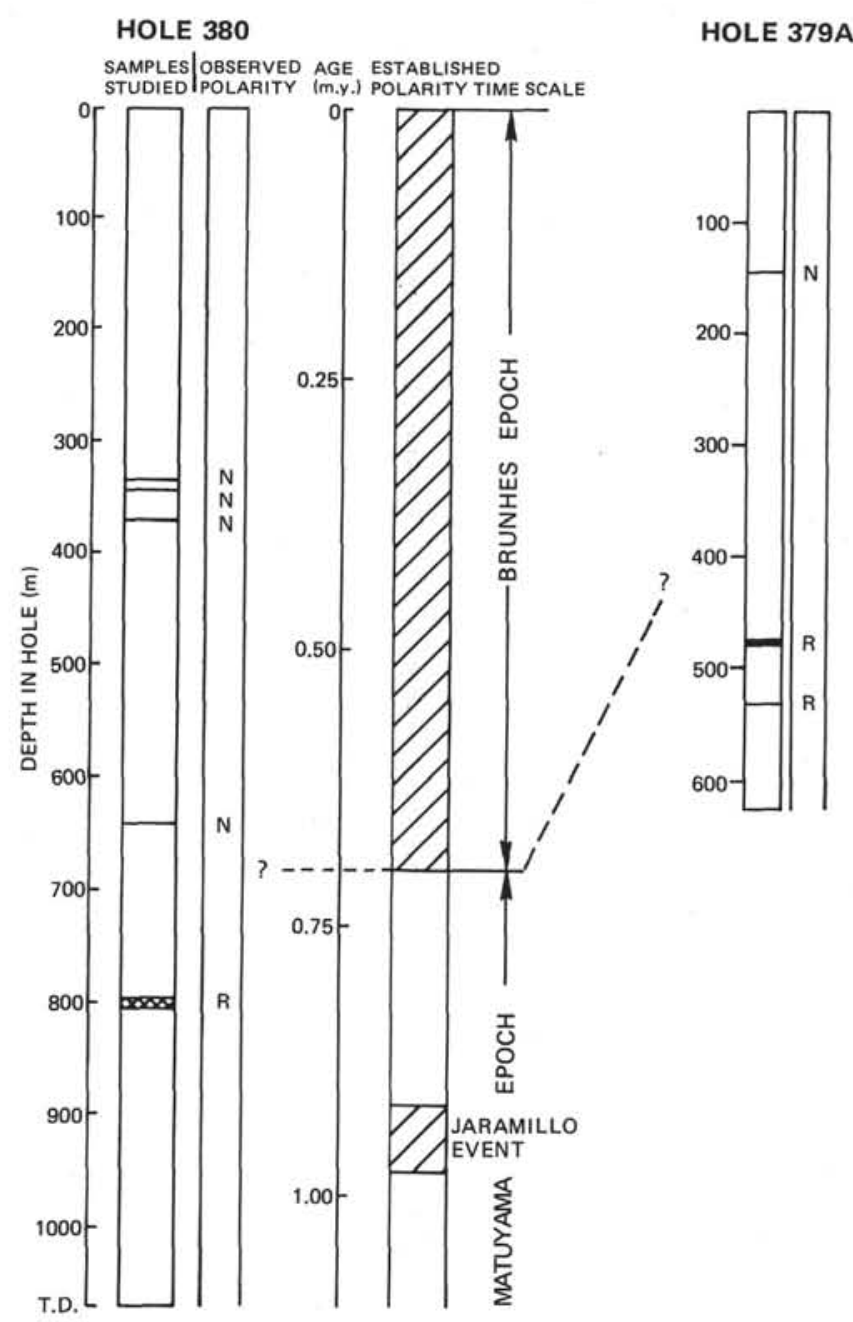

Figure 7. Comparison of magnetic polarity determination at Holes 380/380A and 379 A with geomagnetic reversal time scale of Tarling and Mitchell (1976). 